\title{
Atrial Ablation
}

National Cancer Institute

\section{Source}

National Cancer Institute. Atrial Ablation. NCI Thesaurus. Code C80432.

A invasive therapeutic procedure to destroy the tissue in the cardiac atria that is the source of an arrhythmia. 